\title{
The Duties and Functions Performance of Aceh Human Resources Improvement Institutions in Scholarship Study Program Implementation in Aceh Government
}

\section{Irfansyah}

STIKES assyifa Aceh, Indonesia

Email: irfansyah_aceh@yahoo.co.id

\begin{abstract}
:
The ability of employees in carrying out the duties and functions of LPSDM can be manifested if the employee has good work motivation, both physiologically, safety, appreciation, social, and self-actualization. the fact shows that LPSDM Aceh has not been able to carry out its duties and functions properly. On the other hand, LPSDM Aceh has not been able to transparently select scholarship recipients. This happens because there are still many recipients of entrusted scholarships from the Aceh government, so that the LPSDM does not appear to be independent in distributing scholarships. The formulation of this thesis problem is How the tasks and functions of the Aceh Human Resources Improvement Institution (LPSDM) in the implementation of further study scholarship programs in Aceh Government and how the performance of employees of the Aceh Human Resources Development Agency (LPSDM) in implementing the scholarship program at the Aceh Government. The purpose of this research is to find out and analyze the tasks and functions of the Aceh Human Resources Improvement Institution (LPSDM) in the implementation of further study scholarship programs in Aceh Government and to find out and analyze the performance of Aceh Human Resources Development Agency (LPSDM) employees in implementing the scholarship program at the Aceh Government. This study uses a qualitative approach with as many as 5 people informants consisting of thus the research assign research informants as many as 4 people consisting of the Head of the LPSDM Secretariat, Sub Division of Finance, Planning and Treasurer Routine. Data collection is done by using observation, interview and documentation techniques. The results of the study prove that the duties and functions as well as the performance of LPSDM Aceh in the implementation of further study scholarship programs in Aceh Government have not been carried out in accordance with Aceh's Governor Regulation No. 11 of 2016 concerning LPSDM Aceh. Thus it can be concluded that the duties and functions of the Aceh Human Resources Improvement Institution (LPSDM) as the implementer of the advanced study scholarship program at Aceh Government can be seen the speed of access, so as to have equal rights between various groups.
\end{abstract}

Keywords:

duties and functions; institute for human resource improvement; advanced study scholarships

\section{Introduction}

LPSDM as an independent institution formed by Aceh Government with the aim to facilitate the implementation of further study scholarship programs. The existence of the institution is felt to be important, because it is the only institution that manages the improvement of human resources through scholarship distribution. To succeed the implementation of the scholarship program, the LPSDM needs to be supported with various abilities, especially the ability of employees, so that the implementation of further study scholarship programs can run as expected. The condition of human resources of the apparatus is still very low, so that LPSDM is obliged to increase human resources by providing training 
and education to the State Civil Apparatus.

The portrait of the apparatus of human resources currently shows low professionalism, the many practices of $\mathrm{KKN}$ involving apparatuses, inadequate salary levels, and service to people who are convoluted, less creative and innovative. The picture gives encouragement to make changes to the human resources of the state apparatus. Increasing human resources has implications for improving organizational performance and is a management tool for realizing one's professionalism in structural and functional positions. But the problems that arise are the low quality and incompatibility of competencies they have, errors placement and unclear career paths that can be taken.

Based on empirical facts obtained through observations, it shows that human resources cannot be improved even though LPSDM annually distributes educational assistance through scholarships for advanced studies due to the low interest of the community in pursuing higher education. On the other hand, the tasks and functions of the Aceh LPSDM were not carried out properly, causing the distribution of educational assistance scholarships for further study often hampered. Meanwhile, the performance of Aceh LPSDM employees also has not shown improvement. This occurs because the placement of Aceh LPSDM employees is not in accordance with their respective fields of expertise and qualifications, resulting in slow completion of the tasks assigned to them. The fact shows that LPSDM Aceh has not been able to carry out its duties and functions properly. This happens because there are still many recipients of entrusted scholarships from the Aceh government, so that the LPSDM institution does not appear to be independent in distributing scholarships.

Aceh Government needs to encourage transparency and improve the performance of Aceh LPSDM employees so that they can work in accordance with their main duties and functions in the implementation of the scholarship program for further studies to run well in line with the expectations of the people of Aceh. The objectives to be achieved in this research are to analyze the tasks and functions of the Aceh Human Resources Improvement Institution (LPSDM) in the implementation of further study scholarship programs in Aceh Government as well as to find out and analyze the performance of Aceh Human Resources Improvement Institution (LPSDM) employees in their implementation scholarship program with the Government of Aceh.

\section{Review of Literature}

\subsection{Theory of Public Policy Implementation}

Implementation is a study of policy studies that lead to a very complex and often politically charged implementation process. Bardach (2011) describes implementation as "Coverage to create a program and general policy that looks good on paper". Policy implementation according to Nugroho (2014) explains that "Policies that can be directly implemented without requiring derivative policies, such as Presidential Decree, Presidential Instruction, Ministerial Decree, Decree of the Regional Head, Decree of the Head of Service, etc., and policies that require public policies such as laws and regulations ".

Another definition of policy implementation was stated by Daniel Mazmanian (2013) that "Implementation of basic policy decisions, usually in the form of laws, but can also take the form of orders or important executive decisions or decisions of the judiciary". On the other hand, Meter in Wahab (2012 :) defines policy implementation as "Actions taken either by individuals or officials or groups of government or private that are directed at the 
achievement of the objectives outlined in the policy decision. ".

Based on the opinion above, it can be seen that the study of public policy implementation involves three things, namely (1) the existence of objectives or policy objectives, (2) the existence of activities or activities to achieve the objectives and (3) the results of the activities. Implementation study is a study of policy studies that lead to the implementation process of a policy.

In managing the scholarship program, collaboration with various related institutions is needed. Cooperation is one form of social interaction. Distribution of scholarships to prospective recipients also needs to be properly monitored. Supervision is all activities to ensure and guarantee that the task / work have been carried out in accordance with the established plan. Thus, it can be concluded that the purpose of supervision to find out the work implementation, work results, and everything whether in accordance with what is planned or not, after measuring the level of errors that occur so that it can be corrected in a better direction.

\subsection{Organizational Theory}

Organization is an important element and is needed in human life. Formal Organizations have a clear structure and division of tasks. The organization is a collection of people who are collaborating through the division of labor to achieve general objectives. For this reason, it can be understood that humans who join an organization have an ongoing bond.

An organization needs to have the following principles or organizational principles such as clear objectives, delegation of authority or division of tasks, accountability in performing tasks, balance between workloads, rewards, working time and work results. Then leadership means a lot to an organization. All activities are carried out by the leader. The leader is also responsible for the progress and setbacks of the organization.

\subsection{Theory of Human Resources}

Human Resources are a crucial problem in an organization to be considered for the progress of the organization or company as expected. Human Resource Development as an effort to improve the quality of the personality, knowledge, skills and abilities of employees. The quality of employees has multi dimensions and has a broad scope along with changing needs. In general, the scope of the dimensions includes changes that are not only required to be more efficient and effective in carrying out tasks, but more than that employees are expected to be better able to anticipate problems that occur in carrying out tasks with increasingly established moral qualities, dedicated and high discipline. namely:

According to Robbin in Yusdi (2010) the ability consists of two groups of factors,

a. Intellectual ability (intellectual ability) is the ability needed to perform various mental activities - thinking, reasoning and problem solving

b. Physical ability, namely the ability to perform tasks that require stamina, skills, strength, and similar characteristics.

c. The ability of an individual is determined by three aspects of basic conditions, namely sensory and cognitive conditions, knowledge of how to respond correctly, and the ability to carry out these responses. 


\subsection{Performance Theory}

People with high performance are usually called productive people and conversely people whose level of performance does not reach the standard are said to be Timpe (2012) is "The level of achievement of a person or employee in an organization or company that can increase productivity. Performance according to Meiner (2015: 43) is "The success that an individual can achieve in doing his work, where the measure of success achieved by an individual cannot be compared to other individuals. The success achieved by an individual is based on the applicable measurement and adjusted to the type of work.

Employee performance is closely related to the results of one's work in an organization or company. The results of the work can involve quality, quantity, and timeliness, but performance evaluation in a company's organization is key in employee development. Performance evaluation is in principle a manifestation of an employee's performance appraisal form.

\section{Research Method}

This study uses a qualitative method because the researcher intends to obtain an indepth picture of a particular social phenomenon in the sense of describing the tasks and functions as well as the performance of the LPSDM as the implementer of the further study scholarship program. With regard to qualitative research, Sugiyono (2015) outlines as follows:

The qualitative research method is called the new method, because of its recent popularity, it is called the post positivistic method because it is based on the philosophy of post positivism. This method is also referred to as an artistic method, because the research process is more art (less patterned), and is also called an interpretive method because the research results are more concerned with interpretation of data found in the field.

According to Moleong (2014: 5) that "qualitative research methods are easier to adjust to field conditions, more sensitive to changes in patterns / values even data in the field". This study uses a qualitative approach that focuses more on the results of interviews with informants. So that the data collected through observation and in-depth interviews with various sources, then data analysis in qualitative research is more focused during the process in the field together with data collection.

Data analysis as the middle stage of a series of stages in a study that has a very important function. The results of the study were obtained, of course, based on the data analysis process first so that the data was valid and could be justified, then the validity of the data was carried out in three ways by referring to the opinions expressed by Moleong (2014), namely:

1. Perseverance Observation.

2. Data Triangulation.

3. Discussion with colleagues.

\section{Result and Discussion}

This research was conducted to examine the tasks and functions and performance of the Aceh Human Resources Development Agency (LPSDM) in the implementation of further study scholarship programs in Aceh Government.. In its development, LPSDM has managed regional finances through the distribution of scholarships to students studying in various 
countries. However, LPSDM scholarship recipients are all Acehnese who have passed the selection process as stated in Governor Regulation Number. However, in the selection process of LPSDM scholarship funds requires a number of mandatory requirements that must be fulfilled by prospective scholarship recipients, including active lecture letters, cumulative achievement index (GPA), certificate of disability and recommendations from universities. This requirement is considered by LPSDM when the selection of scholarship recipients is conducted.

The results showed that there was an indication of the game in the distribution of educational aid funds because none of the doctoral program students got it both domestically and abroad. However, all tertiary and international tertiary institutions were late sending student data verification. However, universities agree or together in the delay in sending student data, so it is very difficult to accept logic. The results of observations are clear that the LPSDM policy related to the requirements of toefl score for scholarship recipients also received sharp criticism from various parties. Toefl score requirements are considered irrelevant for prospective scholarship recipients who only continue their education at tertiary institutions in Aceh or domestically.

Based on the results of the study showed that the majority of recipients of LPSDM education assistance costs were mostly not permanent recipients, but the results of the selection made by LPSDM through various forms of information distributed. On the other hand, the number of recipients of tuition assistance distributed through LPSDM has increased every year. Thus proving that the number of recipients of tuition assistance is highly dependent on the costs budgeted by the Aceh Government.

\section{Conclusion}

Based on the discussion as described above, it can be concluded that the tasks and functions of the Aceh Human Resources Development Agency (LPSDM) as the implementer of the advanced study scholarship program at the Aceh Government can be seen in terms of speed of access, so as to have equal rights between various groups. On the other hand operational policies also include coverage, namely the number of scholarship assistance recipients each year. Seen from the aspect it can be seen that in the distribution of educational assistance funds conducted by LPSDM never experienced irregularities, because LPSDM always conducts strict selection. The selection carried out by LPSDM aims to overcome the occurrence of irregularities in the distribution of tuition assistance. Likewise, services in the distribution of education costs assistance conducted by LPSDM Aceh require accuracy in terms of time and targets, so that the distribution of scholarships by LPSDM Aceh is in accordance with the scholarship procurement program set by the Aceh Government.

Then relating to the performance of employees of the Aceh Human Resources Improvement Institute (LPSDM) in the implementation of further study scholarship programs at Aceh Government in Aceh carrying out various strategies to develop education aid funds. One of the strategies used by LPSDM Aceh is through an effort to find donors who are willing to channel educational assistance costs to the people of Aceh. On the other hand, the distribution of educational assistance by LPSDM Aceh is carried out in accordance with the concept of administration, so that the process of channeling education assistance does not experience deviations. However, the existence of LPSDM Aceh scholarships is often used for the political interests of certain parties. Therefore, the distribution of Aceh LPSDM scholarships was transferred directly to the scholarship recipient's account. 


\section{References}

Bardach. (2011). Prinsip-prinsip Kebijakan Negara. Jakarta: Pustaka al-Husna.

Mesiono. (2013). Pengantar Teori dan Praktik Analisis Kebijakan. Jakarta: Kencana.

Moleong, J. Lexy. (2014). Metode Penelitian Kualitatif.Bandung: Remaja Rosda Karya.

Nugroho, Riant. (2014). Teori, Manajemen, Dinamika Analisis, Konvergensi, Dan Dinamika Kebijakan. Jakarta: Elex Kompotindo.

Sugiyono. (2015). Metode Penelitian Kuantitatif Kualitatif dan R\&D. Bandung: Alfabeta.

Timpe, Dale. (2012). Seri Ilmu dan Seni Manajemen Bisnis (Memimpin Manusia). Jakarta: Elex Media Komputindo.

Wahab, Solichin. (2014). Analisis kebijaksanaan dari Formulasi ke Manajemen Pelayanan Umum di Indonesia. Jakarta: Bumi Aksara.

Yusdi, Milma. (2010). Kamus Umum Bahasa Indonesia, Jakarta: Pustaka Sinar 